\title{
Expression of a Fungal Glucose Oxidase Gene in Three Potato Cultivars with Different Susceptibility to Late Blight (Phytophthora infestans Mont. deBary)
}

\author{
Kimberly J. Felcher and D.S. Douches ${ }^{1}$ \\ Department of Crop and Soil Sciences, Michigan State University, East Lansing, MI 48824 \\ W.W. Kirk and R. Hammerschmidt \\ Department of Plant Pathology, Michigan State University, East Lansing, MI 48824 \\ W. Li \\ Department of Crop Sciences, University of Guelph, Guelph, Ontario, Canada NIG2WI
}

ADDitional INDEX WORDS. Solanum tuberosum, potato, transformation, glucose oxidase

\begin{abstract}
Research was done to determine if enhanced resistance to potato (Solanum tuberosum $\mathrm{L}$.) late blight could be obtained by combining host plant resistance and engineered resistance. Late blight susceptible cultivars, Atlantic, and Spunta and the partially resistant cultivar Libertas were transformed with a fungal glucose oxidase gene, resulting in lines which ranged in transgene copy number from 1 to 8 . Glucose oxidase enzyme activity ranged from 0.00 to $96.74 \times 10^{-5} \mathrm{units} / \mathrm{mg}^{\mathrm{plant}}$ tissue. There was no correlation between copy number and level of transgene mRNA, level of transgene mRNA and enzyme activity, or between level of enzyme activity and disease resistance. Field and growth chamber evaluation of late blight response demonstrated little to no effect of the glucose oxidase transgene in either late blight susceptible or partially late blight resistant cultivars. However, enzyme activity levels were much lower than levels reported in previous research, which may account for the lack of effect of glucose oxidase against Phytophthora infestans. Twenty-one percent of the transgenic lines were phenotypically off-type compared to nontransgenic controls. Most of the off-type transgenic lines (four out of seven) were derived from 'Libertas'. Because several off-type lines did not express the glucose oxidase protein, this phenomenon could not be attributed solely to the glucose oxidase transgene. Based on these results, transgenic lines produced for this study do not increase resistance to $P$. infestans even in combination with moderate host plant resistance. However, production of greater numbers of transgenic lines with the current construct or, production of transgenic lines in which a different constitutive promoter drives the expression of the glucose oxidase gene might result in greater disease resistance. However, the usefulness of any small increase in resistance would need to be evaluated against the time and cost required for development of transgenic potato cultivars and the potential for off-type tubers and plants.
\end{abstract}

Late blight, caused by the oomycete Phytophthora infestans (Mont.) deBary, is a serious disease of potato (Solanum tuberosum subsp. tuberosum L.) in many areas of the world (Fry and Goodwin, 1997). Economic losses due to this disease occur by reduced photosynthetic capacity resulting in yield reduction and by tuber infection resulting in storage losses. Foliar infection first appears as water-soaked lesions that enlarge rapidly under moist, cool conditions and become brown and irregular in shape (Draper et al., 1994). White mycelial growth is often observed on the lower leaf surfaces. Tuber infection is indicated by irregular, slightly sunken, dark patches on the tuber surface and by brown discoloration extending into the tuber tissue (Lacy and Hammerschmidt, 1995).

Currently, the strategy for controlling potato late blight in the United States is a combination of cultural and management practices such as the use of certified seed, elimination of cull piles and the use of protectant fungicides (Lacy and Hammerschmidt, 1995). At present there are no late blight resistant potato cultivars that are acceptable for North American commercial markets (Douches et al., 1997). Therefore, many potato breeding programs are emphasizing the development of late blight resistant cultivars. Several sources of late blight resistance have been identified in wild species, foreign cultivars and somatic hybrids (Bamberg et al., 1994; Douches et al., 1997, 2000; Helgeson et al., 1998). By combining these different sources of resistance, it may be possible to pyramid different mechanisms of resistance into one genotype and thereby

Received for publication 5 Apr. 2002. Accepted for publication 1 Nov. 2002. ${ }^{1}$ Corresponding author; e-mail: douchesd@msu.edu. develop stronger and more durable resistance to potato late blight. Combining a transgenic source of resistance with moderate levels of natural late blight resistance may provide another means to develop a potato cultivar with stronger more durable resistance.

One gene that has been used to increase disease resistance in potato is the glucose oxidase ( $\beta$-D-glucose:oxygen 1-oxidoreductase, EC 1.1.3.4) gene isolated from the fungus, Aspergillus niger. Frederick et al. (1990) cloned and sequenced this gene and it was subsequently transformed into the potato cultivar Russet Burbank (Wu et al., 1995). Transgenic plants were shown to have increased resistance to bacterial soft rot caused by Erwinia carotovora ssp. Carotovora (Jones) Dye, Verticillium wilt caused by Verticillium dahliae Reinke and Berth. and to late blight caused by $P$. infestans. This increased resistance has been attributed to the accumulation of hydrogen peroxide from the oxidation of $\beta$-D-glucose by glucose oxidase. Hydrogen peroxide has been reported to function at several points in the plant disease response including direct antimicrobial effect (Wu et al., 1995), structural changes in the plant cell wall (Brisson et al., 1994; Dean and Kuc, 1987), production of toxic, lipid free radicals (Keppler and Baker, 1989), activation of phytoalexin synthesis (Apostol et al, 1989; Chai and Doke, 1987).

Regardless of the precise function of $\mathrm{H}_{2} \mathrm{O}_{2}$ in plant disease resistance, manipulation of $\mathrm{H}_{2} \mathrm{O}_{2}$ levels in potatoes with the incorporation of the glucose oxidase gene has been shown to provide some resistance to late blight and other diseases (Wu et al., 1995, 1997). To date only one cultivar (Russet Burbank) has been transformed with the glucose oxidase gene and these transformants demonstrated either a reduction in symptom severity and/or a delay in 
symptom development when challenged with $P$. infestans and other pathogens (Wu et al., 1995, 1997). Developing potato cultivars with less susceptibility to late blight may be useful for reducing the amount of fungicide necessary for control. However, the ultimate goal is to develop completely resistant cultivars. One way this may be accomplished is by pyramiding engineered resistance mechanisms with natural host plant resistance. Therefore, this study was undertaken to test the effectiveness of the glucose oxidase gene on its own by transforming late blight-susceptible cultivars, and to test the effectiveness of the gene in combination with natural late blight resistance by transforming a partially resistant cultivar.

\section{Materials and Methods}

\section{Cloning of the glucose oxidase gene}

The glucose oxidase gene was cloned from Aspergillus niger (ATCC strain 9029) using the polymerase chain reaction (PCR) and primers designed according to Frederick et al. (1990) to which SmaI and $\mathrm{XbaI}$ restriction sites had been added. The resulting DNA fragment was sequenced for verification, compared to the published sequence (Frederick et al., 1990) and incorporated into the pE1102 vector. The resulting plasmid, pSPUD11 (Fig. 1), had the glucose oxidase gene under the control of the Gelvin "super promoter" (Ni et al., 1995). This promoter is a combination of a trimer octopine synthase upstream activating sequence (ocs) ${ }_{3}$ joined to a mannopine synthase (mas) activator and promoter. pSPUD11 also contained the Nos terminator sequence, right and left borders for plant transformation and the NptII gene (kanamycin resistance) as a selectable marker. The pSPUD11 plasmid was transformed intoAgrobacterium tumefaciens strain LBA4404 (Ooms et al., 1982) via triparental mating.

\section{Transformation of potato cultivars}

The cultivars Spunta, Atlantic, and Libertas were micropropagated in GA-7 Magenta vessels each containing $25 \mathrm{~mL}$ of modified MS basal medium (Li et al., 1999). Of these cultivars, Spunta and Atlantic were susceptible to $P$. infestans, whereas 'Libertas' had a moderate level of resistance in greenhouse experiments (D. Douches, unpublished data). Transformations of potato cultivars were done according to $\mathrm{Li}$ et al. (1999) using the A. tumefaciens culture harboring the pSPUD11 vector. Regenerating shoots $(>5 \mathrm{~mm})$ were excised and transferred individually into $25 \times 100 \mathrm{~mm}$ glass tubes each containing $20 \mathrm{~mL}$ of MS medium (Douches et al., 1998) supplemented with $200 \mathrm{mg} \cdot \mathrm{L}^{-1}$ Timentin (SmithKline Beecham, Philadelphia, $\mathrm{Pa}$.) and $50 \mathrm{mg} \cdot \mathrm{L}^{-1} \mathrm{kanamycin}$. Rooted plantlets were designated as SGO-\# (derived from 'Spunta'), AGO-\# (derived from 'Atlantic'), and LGO-\# (derived from 'Libertas'). Named plantlets were subcultured and subsequently transplanted into 10$\mathrm{cm}$ pots containing Bacto potting medium (Michigan Peat Co., Houston, Texas) and grown in the greenhouse under high pressure sodium lights ( $16 \mathrm{~h}$ photoperiod) at 23 to $27^{\circ} \mathrm{C}$. Leaf tissue from these plants was used for the molecular characterization and enzyme activity assays.

\section{Molecular characterization of transgenic potato lines}

Southern ANALYSIS. DNA was extracted from each putative transgenic line (Saghai-Maroof et al., 1984) and used for Southern blotting to verify incorporation of the glucose oxidase transgene and to determine copy number. Genomic DNA (20 mg) was digested with $\mathrm{BamHI}$ to excise the glucose oxidase gene for hybridization with a glucose oxidase
DNA probe. Digestion with $\mathrm{XbaI}$ was used to determine copy number. DNA fragments were electrophoretically separated through a $1 \%$ agarose gel and transferred onto a nylon membrane (Hybond N, Amersham, U.K.). Prehybridization was conducted for $2 \mathrm{~h}$ at 42 ${ }^{\circ} \mathrm{C}$, followed by an overnight hybridization ( $\mathrm{Li}$ et al., 1999). The hybridization solution contained a probe that was random primed labeled using DIG-11-dUTP according to the manufacturer's instructions (Roche Molecular Biochemicals, Germany). Following hybridization, the membrane was washed twice in $2 \times \mathrm{SSC}, 0.1 \%$ SDS for $15 \mathrm{~min}$ at room temperature and then twice in $0.5 \times \mathrm{SSC}$, $0.1 \%$ SDS for $15 \mathrm{~min}$ at $65^{\circ} \mathrm{C}$. Chemiluminescent detection was according to Li et al. (1999). Each line was scored for the presence or absence of the glucose oxidase gene and the number of inserts.

NorTHERN ANALYSIS. Healthy tissue $(1 \mathrm{mg})$ was collected from recently expanded leaves of greenhouse-grown plants of each transgenic potato line and frozen immediately in liquid nitrogen. Frozen tissue was stored at $-80^{\circ} \mathrm{C}$. Total RNA was isolated using Qiagen RNeasy Plant Total RNA Kit (Qiagen, Chatsworth, Calif.) and quantified by spectrophotometry. Northern analysis was conducted according to Li et al. (1999) to verify the presence of the glucose oxidase transcript. To prepare a DIG-11-dUTP labeled RNA probe, the first half of the glucose oxidase $(1.5 \mathrm{~kb})$ was transferred to the Bluescript" $\mathrm{SK}^{+/-}$plasmid (Stratagene, LaJolla, Calif.). The resulting vector was transformed into Eschericia coli strain DH5 $\alpha$, and the glucose oxidase RNA probe was synthesized by in vitro RNA transcription using an RNA labeling kit (Roche Molecular Biochemicals, Germany). After detection of the glucose oxidase transcript by northern analysis, each blot was then hybridized with a DIG-11-dUTP labeled 18S ribosomal probe (synthesized in the same manner as the glucose oxidase RNA probe) to determine if the amount of total RNA in each lane was about equal. For this probe, a prehybridization/hybridization temperature of 42 ${ }^{\circ} \mathrm{C}$ was used, but all other conditions were as described by Li et al. (1999). Relative levels of glucose oxidase transcript were determined on each individual blot.

WESTERn ANALYSIS. Total protein was extracted from fresh leaf tissue $(0.2 \mathrm{~g})$ by grinding in $800 \mathrm{~mL}$ of extraction buffer $(50 \mathrm{~mm}$ Tris $\mathrm{HCl}$ pH 8.0, 1 mм EDTA, 10 mm diethyldithiocarbamic acid, 0.05\% Tween 20). A Bradford protein assay (BioRad, Hercules, Calif.) was conducted on the soluble leaf extracts to quantify the amount of protein in each sample. Based on the estimated amount of protein in each sample, $200 \mathrm{mg}$ of total protein were loaded on a $10 \%$ SDSPAGE gel in addition to $50 \mathrm{ng}$ purified glucose oxidase enzyme (Sigma, St. Louis, Mo.). Identical samples were loaded onto a second gel, and both gels were subjected to overnight electrophoresis at $45 \mathrm{~V}$. Subsequently, one of the gels was stained with Coomassie Brilliant Blue R-250 solution to visually compare loading. The other gel was transferred, via western blotting, to a membrane and probed with a 1:40,000 dilution of glucose oxidase rabbit polyclonal antibody (Polysciences, Inc., Warrington, Pa.) and an alkaline phosphatase conjugated antirabbit IgG (Li et al., 1999). Antibody binding was detected with CSPD (disodium 3-(4-methoxyspiro \{1,2dioxetance-3,2'(5'-chloro)tricyclo[3.3.1.1 $\left.{ }^{3,7}\right]$ decan $\left.\}-4-y l\right)$ phenyl-

Fig. 1. pSPUD11 vector used for transformation. The glucose oxidase gene was under the control of the Gelvin super promoter [P(ocs $)_{3}$ mas] and the NPTII gene for kanamycin resistance was used as the selectable marker.

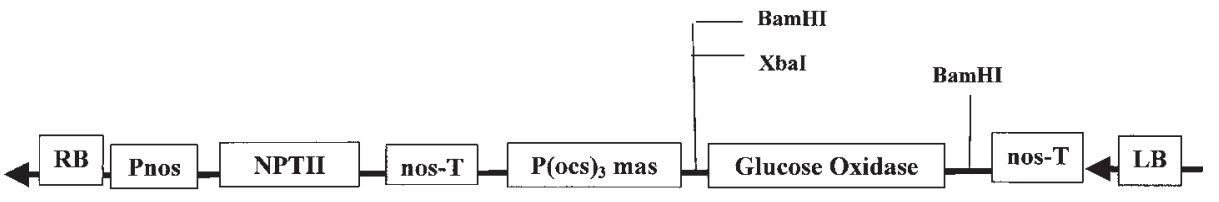


phosphate) according to the manufacturer's instructions (Roche Molecular Biochemicals), and the blot was exposed to X-ray film (Hyperfilm, Amersham).

\section{Glucose oxidase enzyme activity assay}

Glucose oxidase enzyme activity was evaluated in transgenic plants that produced the glucose oxidase protein using a method modified from Gallo (1981) by Wu et al. (1995). Enzyme activity in this assay is indicated by the production of a rose colored pigment. Proteins were extracted from $200 \mathrm{mg}$ fresh leaf tissue by grinding in a potassium phosphate buffer $(25 \mathrm{~mm}, \mathrm{pH} 7.0,5 \mathrm{~mm}$ EDTA $)$ at $4{ }^{\circ} \mathrm{C}$. A dilution series was made from each sample by mixing 10, 20, 30, or $40 \mathrm{~mL}$ of sample with reagent mixture $\left(70 \mathrm{~mm} \mathrm{KH}_{2} \mathrm{PO}_{4}\right.$ buffer, $\mathrm{pH}$ $5.8,0.57 \mathrm{~mm}$ 4-aminoantipyrine, $0.35 \mathrm{~mL} \cdot \mathrm{L}^{-1}$ Triton $\mathrm{X}-100,10 \mathrm{~mm}$ crystalline phenol, 23 units $\mathrm{mL}^{-1}$ horseradish peroxidase, and 175 $\mathrm{mm}$ glucose) for a total reaction volume of $1.0 \mathrm{~mL}$. Known concentrations of purified glucose oxidase were also mixed with the reagent mixture to create a standard curve. Reaction mixtures were incubated at $22{ }^{\circ} \mathrm{C}$ for 10 to $90 \mathrm{~min}$. Following the incubation, absorbance of each sample was measured at $510 \mathrm{~nm}$ using a spectrophotometer. The amount of enzyme (mg enzyme/mg of fresh tissue) was determined for each dilution of a sample based on a standard curve. The glucose oxidase enzyme used to create the standard curve had 15 to 25 Units (U) of activity/mg enzyme without added oxygen (Sigma-Aldrich Co.). Therefore, we used the average value, $20 \mathrm{U} /$ $\mathrm{mg}$ enzyme, to convert $\mathrm{mg}$ enzyme/mg fresh tissue into units of enzyme activity. These values were then multiplied by $10^{5}$. Using dilutions (4) as replications, ANOVA was done using SAS proc glm, and lines were compared to nontransgenic controls with Dunnett's $t$ test (SAS Institute, 1996).

\section{Late blight screening of transgenic lines}

Foliar RESISTANCE. Foliar resistance to late blight was tested both in controlled environment chambers (Douches et al., 1997) and in plots at the Michigan State University (MSU) Muck Soils Research Farm (Bath). Transgenic potato lines were subcultured in $20 \mathrm{~mL}$ of MS medium (Douches et al., 1998) and then planted in the greenhouse in 10-cm-diameter pots containing Bacto potting medium (Michigan Peat Co., Houston, Texas). Before flowering, plants were placed on trays in a controlled environment chamber in a randomized complete block design (RCBD) with four replications and were inoculated with zoospore suspension cultures of $P$. infestans (US8) as outlined by Douches et al. (1997). Plants were rated over time for percent folair area infected. Percentage data were normalized by transformation using the arcsine function. Analysis of variance (ANOVA) was conducted using SAS proc glm, and transgenic lines were compared to the nontransgenic control cultivar from which they were derived using Dunnett's $t$ test (SAS Institute, 1996). Some plantlets did not survive the transfer from tissue culture to the greenhouse and thus, not all lines tested were included in all four replications. When this occurred, least-squares means (LSmeans) were used for comparisons. The $\mathrm{F}_{0 \mathrm{MAX}}$ test was used to determine if trial variances were homogeneous. When the $\mathrm{F}_{\text {OMAX }}$ value was not significant, data were combined across trials and analyzed as indicated above.

Two years of field evaluations for response to $P$. infestans were done on all transgenic lines. Due to plant availability, SGO lines were field tested in 1998 and 1999 whereas, LGO and AGO lines were field tested in 1999 and 2000. Transplants from tissue culture were used for first year field studies, and second year studies were initiated using seed tubers harvested the previous year from agronomic trials at the MSU Montcalm Research Farm. Plants were grown in a RCBD with four replications and five plants per plot with two feet between plots to facilitate evaluation. Zoospore suspension cultures were prepared as described by Kirk et al. (2000). A mixture of $P$. infestans isolates (US8, A2 mating type) collected in Michigan (1994-98) was used each year. Based on detached leaf assays, the mixture of isolates used each year was infectious in all the $\mathrm{R}$ gene differentials except R9 (data not shown). All plants were inoculated with the zoospore suspension cultures of $P$. infestans via a sprinkler irrigation system 42d (1998), 55d (1999), and 57d (2000) after planting. Moisture was maintained on the foliage via misting irrigation. Plots were evaluated over time for percent area infected. The area under the disease progress curve (AUDPC) was calculated as described by Shaner and Finney (1977) and divided by the maximum AUDPC (days after inoculation at last evaluation $\times 100$ ) converting the value to the relative AUDPC (RAUDPC). Statistical analyses and comparisons were conducted as noted above for greenhouse data.

\section{Agronomic trials}

All transgenic lines were evaluated in agronomic field trials at the Montcalm Research Farm, Entrican, Mich. In the 1998 and 1999 trials, tissue culture plantlets were used to establish the research plots, whereas, seed tubers were used in the 2000 trial. Plots were single rows $(7.5 \mathrm{~m}$ long) with plants spaced $30 \mathrm{~cm}$ apart. During the growing season, weed, disease and insect pressure were controlled as per good agricultural practice. Soil moisture was maintained by overhead irrigation. Due to the use of tissue culture plantlets and the late maturity of 'Libertas'- and 'Spunta'-derived lines, the tubers from the 1998 and 1999 trials were very small and had to be hand harvested. Therefore, lines were characterized visually for plant growth habit and tuber morphology, and no formal statistics were used. The plots from the 2000 trial were mechanically harvested and evaluated for size distribution, specific gravity, and internal defects. Analysis of variance (ANOVA) was conducted using SAS proc glm and transgenic lines were compared to the nontransgenic control cultivar from which they were derived using Dunnett's $t$ test (SAS Institute, 1996).

\section{Results}

\section{Transformation and molecular analysis}

Transformation of 'Spunta' and 'Atlantic' resulted in 12 transgenic lines from 'Spunta' and 14 transgenic lines from 'Atlantic' (Tables 1 and 2). However, transformation of 'Libertas' (7 transgenic lines) (Table 3) was more difficult, and this resulted in fewer transformed shoots. Regeneration of transgenic shoots from 'Spunta' and 'Atlantic' occurred within 3 to 5 weeks following cocultivation, and there were multiple shoots per explant. Very few shoots were recovered from 'Libertas', and regeneration occurred 8 to 12 weeks following cocultivation (data not shown).

The copy number of the transgenic lines recovered in this study ranged from one to as many as seven copies in AGO-8 (Tables 1, 2, and 3 ). There was no correlation between copy number and gene silencing. For example, AGO-2 had only one copy of the glucose oxidase transgene but northern analysis revealed a lack of transgene transcription. In contrast, AGO-8 contained seven transgene copies and produced both the transgene transcript and the glucose oxidase protein (Table 2). There were other lines (SGO-1, LGO-1, AGO-5) with only one copy of the transgene which produced relatively high levels of the transgene transcript as well as glucose oxidase protein (Fig. 2). In addition, relative level of transgene mRNA did not always reflect the amount of enzyme activity detected. Lines with 
relatively high transgene mRNA had both high (LGO-1, LGO-4) and low (LGO-10, SGO-2) glucose oxidase enzyme activity (Tables 1 and 3).

Of all the transgenic lines recovered, there were 9 AGO lines, 5
LGO lines, and 6 SGO lines that produced the glucose oxidase protein (Tables 1, 2, and 3). Further analyses were limited to AGO, LGO, and SGO lines in which western analysis revealed the presence of glucose oxidase protein $(\approx 80 \mathrm{kDa})$ (Fig. 2).

Table 1. Molecular analyses of transgene expression, field and greenhouse late blight experiments and tuber phenotype of 'Spunta'-derived (SGO) lines containing the glucose oxidase gene.

\begin{tabular}{|c|c|c|c|c|c|c|c|c|}
\hline \multirow[b]{2}{*}{$\begin{array}{l}\text { SGO } \\
\text { line }\end{array}$} & \multicolumn{4}{|c|}{ Molecular characterization } & \multicolumn{2}{|c|}{ Foliar late blight evaluations $^{\mathrm{x}}$} & \multicolumn{2}{|c|}{ Tuber phenotypes" $^{\text {" }}$} \\
\hline & $\begin{array}{c}\text { Copy } \\
\text { no. }\end{array}$ & $\begin{array}{c}\text { Northern } \\
\left(_{\text {leaf })^{z}}\right.\end{array}$ & $\begin{array}{l}\text { Glucose } \\
\text { oxidase } \\
\text { enzyme } \\
\text { Western }\end{array}$ & $\begin{array}{c}\text { Greenhouse } \\
(\% \text { area } \\
\text { activity }^{\mathrm{y}}\end{array}$ & $\begin{array}{c}\text { Field } \\
\text { infected) }\end{array}$ & $\begin{array}{c}\text { Plants } \\
\text { Tissue } \\
\text { culture } \\
\text { (RAUDPC) }\end{array}$ & $\begin{array}{c}\text { from } \\
\text { seed } \\
\text { plantlets }\end{array}$ & tubers \\
\hline$\overline{\text { Spunta }}$ & 0 & - & - & 0.0 & 84.9 & 25.2 & $\mathrm{~T}$ & $\mathrm{~T}$ \\
\hline 1 & 1 & +++ & + & $19.7^{*}$ & $41.0^{*}$ & 25.2 & $\mathrm{~T}$ & $\mathrm{~T}$ \\
\hline 2 & 1 & +++ & + & 4.4 & $41.2^{*}$ & 28.7 & $\mathrm{~K}$ & $\mathrm{~T}$ \\
\hline 3 & 2 & +++ & + & $18.6^{*}$ & 73.7 & $29.7^{*}$ & $\mathrm{~K}$ & $\mathrm{~K}$ \\
\hline 4 & 3 & ++ & - & ND & ND & ND & ND & ND \\
\hline 9 & 3 & + & + & 0.0 & $42.5^{*}$ & $29.6^{*}$ & $\mathrm{~T}$ & $\mathrm{~T}$ \\
\hline 10 & 1 & - & - & ND & ND & ND & ND & ND \\
\hline 12 & 1 & +++ & + & $30.4^{*}$ & $40.8^{*}$ & 25.4 & $\mathrm{~T}$ & $\mathrm{~T}$ \\
\hline 14 & 1 & ++ & + & 6.4 & $26.9^{*}$ & 25.6 & $\mathrm{~T}$ & $\mathrm{~T}$ \\
\hline 19 & 3 & ++ & - & ND & ND & ND & ND & ND \\
\hline 20 & 2 & - & - & ND & ND & ND & ND & ND \\
\hline 23 & 3 & + & - & ND & ND & ND & ND & ND \\
\hline 26 & 5 & +++ & - & ND & ND & ND & ND & ND \\
\hline $\mathrm{CV}$ & & & & & $40 \%$ & $11 \%$ & & \\
\hline
\end{tabular}

$\overline{\mathrm{z}}(+)=$ lowest relative band intensity, $(+++)=$ highest relative band intensity.

yUnits of activity in $1 \mathrm{mg}$ of leaf tissue multiplied by $10^{5}$; * significantly different from 'Spunta' $(P<0.05)$.

${ }^{x}$ Data combined over trials (14 DAI, greenhouse) and over years (field); 'significantly different from 'Spunta' $(P<0.05)$.

${ }^{\mathrm{w}} \mathrm{T}=$ typical tuber phenotype; $\mathrm{K}=$ knobby tuber phenotype.

$\mathrm{ND}=$ analysis not done due to the lack of glucose oxidase protein in the transgenic line.

Table 2. Molecular analyses of transgene expression, field and greenhouse late blight experiments and tuber phenotype of 'Atlantic'-derived (AGO) lines containing the glucose oxidase gene.

\begin{tabular}{|c|c|c|c|c|c|c|c|c|c|}
\hline \multirow[b]{2}{*}{$\begin{array}{l}\text { AGO } \\
\text { line }\end{array}$} & \multicolumn{4}{|c|}{ Molecular characterization } & \multicolumn{3}{|c|}{ Foliar late blight evaluations ${ }^{\mathrm{x}}$} & \multicolumn{2}{|c|}{ Tuber phenotypes ${ }^{\mathrm{W}}$} \\
\hline & $\begin{array}{c}\text { Copy } \\
\text { no. }\end{array}$ & $\begin{array}{l}\text { Northern } \\
(\text { leaf) }\end{array}$ & Western & $\begin{array}{l}\text { Glucose } \\
\text { oxidase } \\
\text { enzyme } \\
\text { activity }^{y}\end{array}$ & $\begin{array}{c}\text { Greenhouse } \\
\text { trial } 1 \\
(\% \text { area } \\
\text { infected })\end{array}$ & $\begin{array}{c}\text { Greenhouse } \\
\text { trial } 2 \\
(\% \text { area } \\
\text { infected })\end{array}$ & $\begin{array}{c}\text { Field } \\
\text { (RAUDPC) }\end{array}$ & $\begin{array}{l}\text { Plants } \\
\text { from } \\
\text { tissue } \\
\text { culture }\end{array}$ & $\begin{array}{l}\text { Plants } \\
\text { from } \\
\text { seed } \\
\text { tubers }\end{array}$ \\
\hline Atlantic & 0 & - & - & 2.78 & 30.1 & 27.4 & $\mathrm{~T}$ & $\mathrm{~T}$ & \\
\hline 2 & 1 & - & - & ND & ND & ND & ND & ND & ND \\
\hline 4 & 3 & ++ & + & $47.00^{*}$ & 18.0 & --- & 27.3 & $\mathrm{~T}$ & $\mathrm{~T}$ \\
\hline 5 & 1 & +++ & + & $52.25^{*}$ & $94.4^{*}$ & 78.7 & $23.0 *$ & $\mathrm{~T}$ & $\mathrm{~T}$ \\
\hline 6 & 5 & +++ & + & $24.53^{*}$ & $85.4^{*}$ & 79.7 & 29.2 & $\mathrm{E}$ & $\mathrm{T}$ \\
\hline 7 & 1 & +++ & + & $25.51^{*}$ & 46.2 & 84.6 & 28.9 & $\mathrm{~T}$ & $\mathrm{~T}$ \\
\hline 8 & 7 & +++ & + & 7.69 & 30.1 & 70.5 & 27.3 & $\mathrm{E}$ & $\mathrm{E}$ \\
\hline 9 & 1 & +++ & - & ND & ND & ND & ND & ND & ND \\
\hline 10 & 1 & +++ & - & ND & ND & ND & ND & ND & ND \\
\hline 11 & 2 & +++ & + & $25.04^{*}$ & 34.6 & 62.6 & 27.1 & $\mathrm{E}$ & $\mathrm{T}$ \\
\hline 12 & 4 & +++ & + & $16.52^{*}$ & 39.8 & 73.2 & 27.6 & $\mathrm{~T}$ & $\mathrm{~T}$ \\
\hline 16 & 3 & ++ & - & ND & ND & ND & ND & ND & ND \\
\hline 17 & 1 & +++ & + & $28.55^{*}$ & --- & 81.2 & --- & $\mathrm{E}$ & --- \\
\hline 18 & 2 & +++ & + & $96.74^{*}$ & --- & 66.6 & --- & $\mathrm{E}$ & --- \\
\hline 21 & 3 & +++ & - & ND & ND & ND & ND & $\mathrm{E}$ & ND \\
\hline $\mathrm{CV}$ & & & & & $42 \%$ & $30 \%$ & $11 \%$ & & \\
\hline
\end{tabular}

$\overline{\mathrm{z}}(+)=$ lowest relative band intensity, $(+++)=$ highest relative band intensity.

yUnits of activity in $1 \mathrm{mg}$ of leaf tissue multiplied by $10^{5}$; "significantly different from 'Atlantic' $(P<0.05)$.

xData combined over years (field), greenhouse data reported as LS means; 'significantly different from 'Atlantic' $(P<0.05)$.

${ }^{\mathrm{w}} \mathrm{T}$ = typical tuber phenotype; $\mathrm{K}=$ knobby tuber phenotype; $\mathrm{E}=$ elongated tuber phenotype.

$\mathrm{ND}=$ analysis not done due to lack of glucose oxidase protein in the transgenic line. 
Table 3. Molecular analyses of transgene expression, field and greenhouse late blight experiments and tuber phenotype of 'Libertas'-derived (LGO) lines containing the glucose oxidase gene.

\begin{tabular}{|c|c|c|c|c|c|c|c|c|c|}
\hline \multirow[b]{2}{*}{$\begin{array}{l}\text { LGO } \\
\text { line }\end{array}$} & \multicolumn{4}{|c|}{ Molecular characterization } & \multicolumn{3}{|c|}{ Foliar late blight evaluations ${ }^{\mathrm{x}}$} & \multicolumn{2}{|c|}{ Tuber phenotypes ${ }^{\mathrm{w}}$} \\
\hline & $\begin{array}{c}\text { Copy } \\
\text { no. }\end{array}$ & $\begin{array}{l}\text { Northern } \\
\left(_{(\text {leaf })^{z}}\right.\end{array}$ & Western & $\begin{array}{l}\text { Glucose } \\
\text { oxidase } \\
\text { enzyme } \\
\text { activity }^{y}\end{array}$ & $\begin{array}{c}\text { Greenhouse } \\
\text { trial } 1 \\
\text { (\% area } \\
\text { infected })\end{array}$ & $\begin{array}{c}\text { Greenhouse } \\
\text { trial } 2 \\
\text { (\% area } \\
\text { infected })\end{array}$ & $\begin{array}{c}\text { Field } \\
\text { (RAUDPC) }\end{array}$ & $\begin{array}{l}\text { Plants } \\
\text { from } \\
\text { tissue } \\
\text { culture }\end{array}$ & $\begin{array}{l}\text { Plants } \\
\text { from } \\
\text { seed } \\
\text { tubers }\end{array}$ \\
\hline Libertas & 0 & - & - & 17.85 & 16.5 & 73.0 & 23.4 & $\mathrm{~T}$ & $\mathrm{~T}$ \\
\hline 1 & 2 & +++ & + & $71.12^{*}$ & 9.6 & 49.4 & $35.1^{*}$ & $\mathrm{~K}, \mathrm{E}$ & $\mathrm{K}, \mathrm{E}$ \\
\hline 3 & 3 & + & + & $30.51^{*}$ & 25.3 & 95.2 & 25.7 & $\mathrm{~T}$ & $\mathrm{~T}$ \\
\hline 4 & 2 & ++++ & + & $60.49^{*}$ & --- & 97.1 & 26.2 & $\mathrm{~K}, \mathrm{E}$ & $\mathrm{K}, \mathrm{E}$ \\
\hline 10 & 6 & +++ & + & 23.90 & 41.9 & 77.0 & 25.9 & $\mathrm{~T}$ & $\mathrm{~T}$ \\
\hline 13 & 1 & - & - & ND & ND & ND & ND & ND & ND \\
\hline 15 & 1 & +++ & - & ND & ND & ND & ND & ND & ND \\
\hline 16 & 7 & +++ & + & 19.97 & $66.7^{*}$ & 93.1 & 20.9 & $\mathrm{~K}, \mathrm{E}$ & $\mathrm{K}, \mathrm{E}$ \\
\hline $\mathrm{CV}$ & & & & & $39 \%$ & $42 \%$ & $16 \%$ & & \\
\hline
\end{tabular}

${ }^{\mathrm{z}}(+)=$ lowest relative band intensity, $(+++)=$ highest relative band intensity.

yUnits of activity in $1 \mathrm{mg}$ of leaf tissue multiplied by $10^{5}$; * significantly different from 'Libertas' $(P<0.05)$.

${ }^{x}$ Data combined over years (field), greenhouse data reported as LS means; *significantly different from 'Libertas' $(P<0.05)$.

${ }^{\mathrm{w}} \mathrm{T}$ = typical tuber phenotype; $\mathrm{K}=$ knobby tuber phenotype; $\mathrm{E}=$ elongated tuber phenotype.

$\mathrm{ND}=$ analysis not done due to lack of glucose oxidase protein in the transgenic line.

Plant growth habit and plant and tuber morphology were closely monitored for each of the transgenic lines. Lines SGO-3 and SGO9 exhibited delayed shoot emergence in the field trials (1999 and 2000) at the Montcalm Research Farm. Although tubers of SGO-3 were noted to be small with numerous knobs, tubers of SGO-9 were similar in shape and size to untransformed 'Spunta' (1999 and 2000) (Table 1). Line SGO-4 did not express the glucose oxidase protein, even so, it was stunted in growth and produced small, knobby tubers (Table 1). Analysis of the 2000 field data indicated that SGO-3 had a total yield lower than 'Spunta' but that SGO-2 and SGO-3 had lower percentage of tubers $(P<0.05)$ in the US number 1 category than the 'Spunta' control (Table 4). However, none of the SGO lines were significantly different from 'Spunta' for pick-outs (off-type), internal defects or specific gravity (Table 4).

None of the AGO lines differed from the untransformed 'Atlantic' in growth habit or plant morphology (1999 and 2000). However, several of the AGO lines from the 1999 trial had slightly elongated tubers and AGO-2 was off-type with knobby and elongated tubers despite the lack of glucose oxidase protein (Table 2). However, in the 2000 trial only AGO-8 was noted to be slightly off-type (AGO2 was not included in the 2000 trial due to the lack of glucose oxidase expression) (Table 2). Statistical analysis indicated that AGO-4, AGO-6, and AGO-8 had significantly lower total yield than 'Atlantic' but that there was no difference for percent of tubers classified as US number 1 (Table 5). In addition, there were no AGO lines that were significantly different from 'Atlantic' for pick-outs, internal qualities or specific gravity (Table 5).

Among the LGO lines, LGO-1, LGO-4, LGO-10, and LGO-16 were stunted in growth compared to the untransformed 'Libertas', whereas plants of LGO-3 were the same as the control (1999 and 2000). Because 'Libertas' is a late maturing variety the tubers from the LGO lines and the 'Libertas' control were small. However, tubers of LGO-1, LGO-4, and LGO-16 were also knobby and elongated oxidase antibody
(1999 and 2000) (Table 3). Statistical analysis of the 2000 field trials indicated that all LGO lines except LGO-3 had significantly lower total yield than the 'Libertas' control and all LGO lines had significantly fewer tubers in the US number 1 class than 'Libertas' (Table 6). LGO-1, LGO-4, and LGO-16 had significantly more pick-outs than the 'Libertas' control (Table 6). Internal defects were not evaluated for LGO lines due to the small size of the tubers; however, all lines were similar to 'Libertas' for specific gravity except LGO-4 for which the specific gravity was significantly lower (Table 6).

Lines differed in the ANOVA for enzyme activity among AGO, LGO, and SGO transgenics $(P<0.05)$. Based on Dunnet's $t$ tests, all of the AGO lines except AGO-8 had higher glucose oxidase enzyme activity than the 'Atlantic' control (Table 2). Among LGO lines, LGO-1, LGO-3, and LGO-4 had higher enzyme activity than nontransgenic control (Table 3). Of the SGO lines, only SGO-1, SGO-

Fig. 2. Northern analysis (A) and western analysis (B) of transgenic lines containing the glucose oxidase gene from Aspergillus niger showing variable transgene expression.

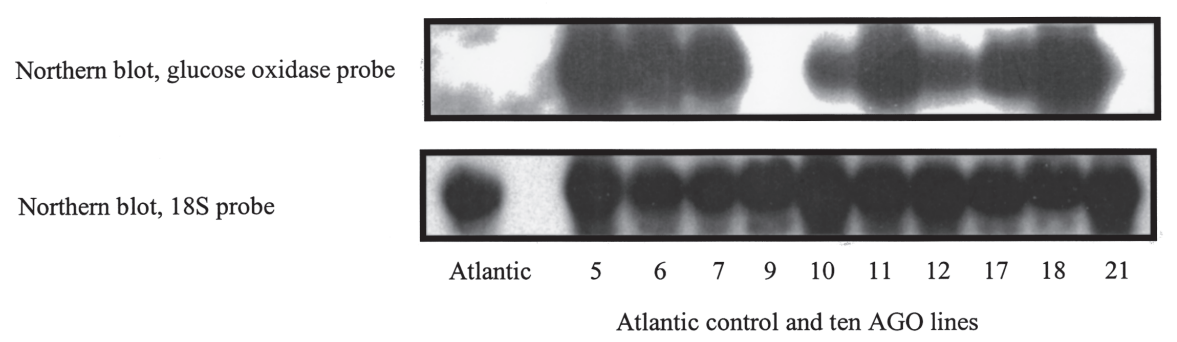

Atlantic control and ten AGO lines

Western blot glucose

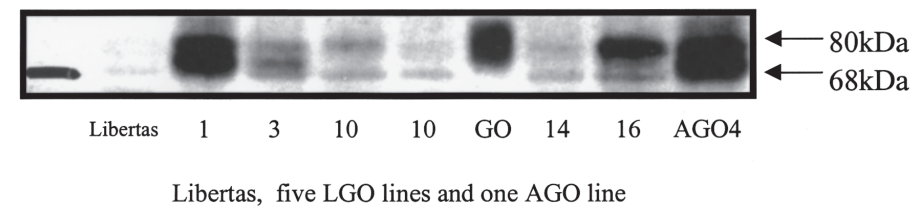


3 and SGO-12 had higher glucose oxidase activity than the 'Spunta' control (Table 1). 'Spunta' and 'Atlantic' had 0.00 and $2.78 \times 10^{-5}$ units of activity per mg of leaf tissue, respectively. 'Libertas', which is moderately resistant to late blight, had $17.85 \times 10^{-5}$ units of activity per milligram of leaf tissue.

\section{Foliar late blight screening}

CONTROLLED ENVIRONMENT STUdiEs. 'Spunta'-derived lines were tested in three separate controlled environment trials. However, data from the second trial could not be combined with either trial one or trial three due to nonhomogenous variation. Using data combined over trials one and three, lines were a significant source of variation at $14 \mathrm{~d}$ after inoculation (DAI) $(p<0.05)$ and lines SGO-1, SGO-2, SGO-9, SGO-12, and SGO-14 were significantly less infected than the 'Spunta' control (Table 1).

Two controlled environment trials of 'Atlantic'-derived and

Table 4. Agronomic evaluation of 'Spunta'-derived (SGO) lines containing the glucose oxidase transgene.

\begin{tabular}{lcccc}
\hline \hline $\begin{array}{l}\text { SGO } \\
\text { line }\end{array}$ & $\begin{array}{l}\text { Total } \\
\text { yield } \\
\text { (cwt) }\end{array}$ & $\begin{array}{c}\text { Percent } \\
\text { US \#1 } \\
\text { tubers }\end{array}$ & $\begin{array}{c}\text { Percent } \\
\text { off-type } \\
\text { tubers }\end{array}$ & $\begin{array}{r}\text { Specific } \\
\text { gravity }\end{array}$ \\
\hline Spunta & 478 & 93 & 3 & 1.061 \\
1 & 418 & 85 & 9 & 1.062 \\
2 & 384 & $75^{*}$ & 11 & 1.065 \\
3 & $273^{*}$ & $67^{*}$ & 17 & 1.055 \\
9 & 412 & 85 & 9 & 1.059 \\
10 & 442 & 89 & 4 & 1.063 \\
12 & 504 & 87 & 6 & 1.063 \\
14 & 485 & 84 & 10 & 1.063 \\
\hline
\end{tabular}

"Significantly different from 'Spunta' $(P<0.05)$.

Table 5. Agronomic evaluation of 'Atlantic'-derived (AGO) lines containing the glucose oxidase transgene.

\begin{tabular}{lcccc}
\hline \hline $\begin{array}{l}\text { AGO } \\
\text { line }\end{array}$ & $\begin{array}{l}\text { Total } \\
\text { yield } \\
\text { (cwt) }\end{array}$ & $\begin{array}{c}\text { Percent } \\
\text { US \#1 } \\
\text { tubers }\end{array}$ & $\begin{array}{c}\text { Percent } \\
\text { off-type } \\
\text { tubers }\end{array}$ & $\begin{array}{r}\text { Specific } \\
\text { gravity }\end{array}$ \\
\hline Atlantic & 523 & 94 & 1 & 1.091 \\
4 & $341^{*}$ & 89 & 1 & 1.095 \\
5 & 458 & 96 & 0 & 1.090 \\
6 & $351^{*}$ & 91 & 2 & 1.087 \\
7 & 463 & 89 & 3 & 1.086 \\
8 & $386^{*}$ & 92 & 2 & 1.081 \\
11 & 442 & 92 & 1 & 1.088 \\
12 & 529 & 89 & 1 & 1.094
\end{tabular}

"Significantly different from 'Atlantic' $(P<0.05)$.

Table 6. Agronomic evaluation of 'Libertas'-derived (LGO) lines containing the glucose oxidase transgene.

\begin{tabular}{lcccc}
\hline \hline LGO & $\begin{array}{c}\text { Total } \\
\text { yield } \\
\text { line }\end{array}$ & $\begin{array}{c}\text { Percent } \\
\text { US \#1 }\end{array}$ & $\begin{array}{c}\text { Percent } \\
\text { off-type } \\
\text { tubers }\end{array}$ & $\begin{array}{c}\text { Specific } \\
\text { gravity }\end{array}$ \\
\hline Libertas & 441 & 77 & 3 & 1.097 \\
1 & $135^{*}$ & $0^{*}$ & $100^{*}$ & 1.090 \\
3 & 329 & $47^{*}$ & 2 & 1.103 \\
4 & $90^{*}$ & $0^{*}$ & $50^{*}$ & $1.087^{*}$ \\
10 & $167^{*}$ & $0^{*}$ & 3 & 1.101 \\
16 & $57^{*}$ & $0^{*}$ & $100^{*}$ & 1.104 \\
\hline
\end{tabular}

"Significantly different from 'Libertas' $(P<0.05)$.
'Libertas'-derived lines were conducted. However, data could not be combined across trials due to nonhomogeneous variation. In the first trial, AGO lines were significantly different at 14 DPI $(P<$ 0.05 ) with lines AGO-5 and AGO-6 having higher infection levels than the 'Atlantic' control $(P<0.05)$ (Table 2). In the second trial, AGO lines were not significantly different at any point following inoculation (Table 2).

In the first controlled environment trial,LGOlines were significantly different at 14 DPI $(P<0.05)$ but none of the transgenic lines were less infected than the 'Libertas' control. However, LGO-16 was more infected than the control (Table 3). In the second trial, lines were not significantly different at any point after inoculation (Table 3).

Field evaluations. In 1998, lines were a significant source of variation $(P<0.05)$. However, based on Dunnett's $t$ test none of the SGO lines differed significantly in resistance $(P<0.05)$ from the 'Spunta' control. Transgenic lines SGO-1, SGO-12, and SGO-14, which were significantly less infected than the control in one of the greenhouse trials, did have lower RAUDPC values than the control, but the difference was not significant. In 1999, SGO lines were not significantly different. However, when data were combined over years lines were significantly different $(P<0.05)$. In the combined analysis, lines SGO-3 and SGO-9 were significantly more infected than the 'Spunta' control $(P<0.05)$ (Table 1).

Lines were not significantly different in the 1999 AGO field trial $(P<0.05)$ but were significantly different in the 2000 field trial. When data were combined across years, lines were significantly different. Based on the analysis of the 2000 data and the combined data, AGO-5 had a significantly lower RAUDPC value than the 'Atlantic' control (Table 2).

In the 1999 LGO field trial lines were not significantly different. However, when the 2000 field data and the field data combined across years were evaluated, lines were significantly different. The RAUDPC values for LGO- 1 and LGO-4 were significantly higher than the RAUDPC for the 'Libertas' control (2000 data). However, when data were combined across years only LGO-1 was significantly different from 'Libertas' (Table 3).

\section{Discussion}

The production of transgenic potato lines containing the glucose oxidase gene was readily achieved for the susceptible cultivars Atlantic and Spunta. However, 'Libertas' was recalcitrant to transformation and resulted in fewer transgenic lines that were recovered only after a lengthy time in in vitro culture. The difference between the cultivars in recovery of transgenic lines may be due to genetic variation for regeneration and transformation efficiency. Several authors have noted such a difference and have developed protocols for efficient regeneration of many cultivars (DeBlock, 1988; Hulme et al., 1992; Wenzler et al., 1989; Yadav and Sticklen, 1995).

Gene silencing occurs either by prevention of transcription, transcriptional gene silencing (TGS) or by alteration and/or destruction of the gene transcript, post-transcriptional gene silencing (PTGS) (Taylor, 1997). Based on northern and western analyses, both TGS and PTGS may have occurred in the glucose oxidase transgenic lines reported on in this study. Lines in which the transgene is present but the transgene transcript is absent suggest TGS, whereas lines in which both the transgene and its transcript are present but the glucose oxidase protein is lacking suggest PTGS (Tables 1, 2, and 3). Although, gene silencing often results from having multiple copies of the same gene (Napoli et al., 1990; Van der Krol et al., 1990) there was no correlation between high copy number and gene silencing among these transgenic lines. 
Although many of the glucose oxidase-containing lines exhibited altered plant growth habit and/or tuber phenotype, these changes cannot be attributed solely to the expression of the transgene because some of these lines did not produce the glucose oxidase protein. For example, tubers of the AGO-2 lines were highly offtype, but neither the glucose oxidase transcript nor the protein was detected in this line (Table 2). Because morphological changes in either the plant or the tuber are not clearly associated with transgene expression, it is possible that these physical changes are due to the position of the transgene insertion and/or somaclonal variation that occurred during the transformation process. Several factors influence the probability that somaclonal variation will occur, including the method of vegetative propagation, type of tissue used, media components, and genotype of the plant (Pierik, 1987). In potato, certain genotypes have a greater tendency for somaclonal variation. Shepard et al. (1980) demonstrated that the cultivar Russet Burbank was very unstable when plants originated from protoplasts. Similar results were found for the cultivar Bintje (Ramula et al., 1984). Regardless of the basis for the altered plant and/or tuber morphology, it is evident that a large percentage of the transgenic plants recovered in this study (21\%) were considered off-type.

In previous research, the glucose oxidase gene was shown to reduce the growth of late blight lesions by $49 \%$ to $56 \%$ compared to controls in detached leaf assays (Wu et al., 1995). In our study, trials conducted in controlled environment chambers indicate a reduction in late blight infection in some SGO lines, whereas field trials indicate little if any effect of the glucose oxidase gene in any of the transgenic lines upon infection by $P$. infestans. There are several possible explanations for the disparity between the research reported in this study and that done by Wu et al. (1995). Glucose oxidase activity in many of the transgenic lines reported in this study was significantly greater than in the nontransgenic controls (Tables 1, 2, and 3). However, increased levels of glucose oxidase did not correlate with increased resistance to late blight. In their patent (\#5,516,671) Lawrence et al. (1996) reported glucose oxidase activity ranging from 0.12 to $18.18 \mathrm{U}$ gram fresh weight. These activity levels are as much as 20 times higher than the activity levels of transgenic lines reported in the current study. Therefore, low glucose oxidase activity may account for the lack of significant resistance to $P$. infestans in 'Spunta', 'Atlantic' and 'Libertas' lines expressing the glucose oxidase gene. However, Lawrence et al. (1996) only report the response of two transgenic lines to $P$. infestans and do not indicate the response of transgenic lines with a range of glucose oxidase activity. Furthermore, in a companion experiment testing the response of transgenic, glucose oxidaseproducing lines to Erwinia caratovora, Lawrence et al. (1996) indicate that lines with high, medium and low glucose oxidase expression (as determined by western blot analyses) reduced the number of colony forming units recovered from disease lesions compared to controls. Therefore, high levels of glucose oxidase expression may not be necessary for disease control. Evaluation of a greater number of transgenic lines in this study may have yielded lines with low expression levels and increased resistance.

Wu et al. (1995) measured the spread of individual lesions in detached leaf assays and the area infected on four center leaves in whole plant analyses, thereby limiting error due to subjective measurements and allowing for the identification of small differences. In the current study, whole plants were evaluated for area infected in both the field and in the greenhouse. The subjectivity in this type of evaluation can lead to high experimental error and limit the ability to identify small differences. In an attempt to limit the subjectivity of these measurements, all analyses were conducted by two or three member teams. Another difference between the two studies is the severity of environmental conditions in which whole plant analyses were conducted. Wu et al. (1995) maintained high humidity in the experimental chamber for only the first $48 \mathrm{~h}$, whereas we maintained high humidity for the entire experiment. Because high humidity favors late blight development, our experimental conditions must be considered more severe and may have prohibited the measurement of small differences in disease severity. Another source of difference may be in the genotype of P. infestans used. In our study, several highly pathogenic isolates of the US-8 genotype of $P$. infestans were used. These isolates had been recovered from infected potato tissue discovered in various Michigan farm locations and would therefore be similar to what potatoes in the field would encounter. Wu et al. (1995) did not report the source or genotype of $P$. infestans used. Lastly, both studies used different glucose oxidase gene constructs for transformation. Our construct used the Gelvin super promoter and utilized the kanamycin resistance gene, NptII, as the selectable marker. The construct used by Wu et al. (1995) used the constitutive figwort mosaic virus 35S promoter and a glyphosate resistance gene as the selectable marker. The DNA sequence of the glucose oxidase gene in both constructs should be the same as both were isolated from Aspergillus niger using primers designed according to the published gene sequence (Frederick et al., 1990). Therefore, the low glucose oxidase activity levels in the 'Spunta', 'Libertas' and 'Atlantic' transgenic lines compared to those in the Lawrence et al. (1996) patent may indicate that the Gelvin super promoter does not function as effectively as the figwort mosaic virus $35 \mathrm{~S}$ promoter in potato. However, a more detailed experiment will be necessary to prove this hypothesis.

Although the ultimate goal is to produce potato cultivars with complete resistance to late blight, cultivars with reduced susceptibility can lessen the frequency and quantity (active ingredient) of fungicide applied (Kirk et al., 2000). With this goal in mind, potentially useful sources of natural and engineered late blight resistance are being evaluated. Transgenic lines produced for this study do not increase resistance to $P$. infestans even in combination with moderate host plant resistance. However, production of greater numbers of transgenic lines with the current construct or production of transgenic lines in which a different constitutive promoter drives the expression of the glucose oxidase gene might result in greater disease resistance.

\section{Literature Cited}

Apostol, I., P. Heinstein, and P. Low. 1989. Rapid stimulation of an oxidative burst during elicitation of cultured plant cells. Plant Physiol. 90:109-116.

Bamberg, J.B., M.W. Martin, and J.J. Schartner. 1994. Elite selections of tuber-bearing Solanum species germplasm. Inter-Regional Potato Introduction Station, NRSP-6, Sturgeon Bay, Wis.

Brisson, L., R. Tenhaken, and C. Lamb. 1994. Function of oxidative crosslinking of cell wall structural proteins in plant disease resistance. Plant Cell 6:1703-1712.

Chai, H. and N. Doke. 1987. Activation of the potential of potato tissue to react hypersensitively to Phytophthora infestans by cytospore germination fluid and the enhancement of this potential by calcium ions. Physiol. Mol. Plant Pathol. 30:27-37.

Dean, R. and J. Kuc. 1987. Rapid lignification in response to wounding and infection as a mechanism for induced systemic protection in cucumber. Physiol. Mol. Plant Pathol. 31:69-81.

DeBlock, M. 1988. Genotype-independent leaf disc transformation of potato (Solanum tuberosum) using Agrobacterium tumefaciens. Theor. Appl. Genet. 76:767-774.

Douches, D., W. Kirk, K. Jastrzebski, C. Long, and R. Hammerschmidt. 
1997. Susceptibility of potato varieties and advanced breeding lines (Solanum tuberosum L.) to Phytophthora infestans (Mont.) De Bary in greenhouse screenings. Amer. Potato J. 74:75-86.

Douches, D.S., A.L. Westedt, K.A. Zarka, W.L. Pett, and E.J. Grafius. 1998. Evaluation of natural and engineered resistance mechanisms in Solanum tuberosum L. for resistance to Phthorimaea operculella Zeller. HortScience 33:1053-1056.

Douches, D., J. Bamberg, W. Kirk, K. Jastrzebski, B.A. Niemira, J. Coombs, D.A. Bisognin, and K.J. Felcher. 2001. Evaluation of wild Solanum species for resistance to the US-8 genotype of Phytophthora infestans utilizing a fine-screening technique. Amer. J. Potato Res. 78:159-165.

Draper, M.A., G.A. Secor, N.C. Gudmestad, H.A. Lamey, and D. Preston. 1994. Leaf blight diseases of potato. N.D. State Univ. Ext. Serv. Bul. PP-I084.

Frederick, K., J. Tung, R. Emerick, F. Masiarz, S. Chamberlain, A. Vasavada, and S. Rosenberg. 1990. Glucose oxidase from Aspergillus niger: Cloning, gene sequence, secretion from Saccharomyces cerevisiae and kinetic analysis of a yeast-derived enzyme. J. Biol. Chem. 265:37933802.

Fry, W.E. and S.B. Goodwin. 1997. Re-emergence of potato and tomato late blight in the United States. Plant Dis. 81:1349-1357.

Gallo, L. 1981. Sterol ester hydrolase from rat pancreas. Methods Enzymol. 71:64-674.

Helgeson, J.P., J.D. Pholman, S. Austin, G.T. Haberlach, S.M. Wielgus, D. Ronis, L. Zambolim, P. Tooley, J.M. McGrath, R.V. James, and W.R. Stevenson. 1998. Somatic hybrids between Solanum bulbocastanum and potato: A new source of resistance to late blight. Theor. Appl. Genet. 96:738-742.

Hulme, J.S., E.S. Higgins, and R. Shields. 1992. An efficient gentotypeindependent method for regeneration of potato plants from leaf tissue. Plant Cell Tissue Organ Cult. 31:161-167.

Keppler, L. and C. Baker. 1989. $\mathrm{O}_{2}^{-}$initiated lipid peroxidation in a bacteria-induced hypersensitive reaction in tobacco cell suspensions. Phytopathology 79:555-562.

Kirk, W.W., D.S. Douches, R. Hammerschmidt, J.M. Stein, K.J. Felcher, K.M. Baker, and B.A. Niemira. 2000. Combining varietal resistance with managed fungicide applications for the control of potato late blight. Afr. J. Crop Sci. 5:329-335.

Lacy, M. and R. Hammerschmidt. 1995. Diseases of potato: Late blight. Mich. State Univ. Ext. Bu. E-1802.

Lawrence, E.B., E.B. Levine, and D.M. Shah. 1996. United States Patent $5,516,671$. Method of controlling plant pathogens.

Li, W., K.A. Zarka, D.S. Douches, J.J. Coombs, W.L. Pett, and E.J. Grafius. 1999. Coexpression of potato $\mathrm{PVY}^{\circ}$ coat protein and cryV-Bt genes in potato. J. Amer. Soc. Hort. Sci. 124:218-223.
Napoli, C., C. Lemieux, and R. Jorgensen. 1990. Introduction of a chimeric chalcone synthase gene into petunia results in reversible cosuppression of homologous genes in trans. Plant Cell 2:279-289.

Ni, M., D. Cui, J. Einstein, S. Narasimhulu, C.E. Vergara, and S.B. Gelvin. 1995. Strength and tissue specificity of chimeric promoters derived from the octopine and mannopine synthase genes. Plant $\mathrm{J}$. 7:661-676.

Ooms, G., P.J.J. Hooykaas, R.J.M. Veen, P. Bleelen, T.J.G. RegensburgTuink, and R.A. Schilperoort. 1982. Octopine Ti-plasmid deletion mutants of Agrobacterium tumefaciens with emphasis on the right side of the T-region. Plasmid 7:15-29.

Pierik, R.L.M. 1987. In vitro culture of higher plants. Martinus Nijhoff Publ., Boston.

Ramula, K.S., P. Dijkhuis, S. Roest, G.S. Bokelmann, and B. DeGroot. 1984. Early occurrence of genetic instability in protoplast cultures of potato. Plant Sci. Lett. 36:79-86.

Saghai-Maroof, K.M. Soliman, R.A. Jorgensen, and R.W. Allard. 1984. Ribosomal DNA spacer length polymorphisms in barley: Mendelian inheritance, chromosomal location, and population dynamics. Proc. Natl. Acad. Sci. USA 81:8014-8018.

SAS Institute, Inc. 1996. Version 6.12. SAS Inst., Cary, N.C.

Shaner, G. and R.E. Finney. 1977. The effect of nitrogen fertilization on the expression of slow-mildewing resistance in Knox wheat. Phytopathology 67:1051-1056.

Shepard, J.F., D. Bidney, and E. Shahin. 1980. Potato protoplasts in crop improvement. Science 208:17-24.

Taylor, C. 1997. Comprehending cosuppression. Plant Cell 9:12451249.

Van der Krol, A.R., L.A. Mur, M. Beld, J.N.M. Mol, and A.R. Stuitje. 1990. Flavonoid genes in petunia: addition of a limited number of gene copies may lead to a suppression of gene expression. Plant Cell 2:291299

Wenzler, H. G. Mignery, G. May, and W. Park. 1989. A rapid and efficient transformation method for the production of large numbers of transgenic potato plants. Plant Sci. 63:79-85.

Wu, G. B. Shortt, E. Lawrence, E. Levine, K. Fitzsimmons, and D. Shah 1995. Disease resistance conferred by expression of a gene encoding $\mathrm{H}_{2} \mathrm{O}_{2}$-generating glucose oxidase in transgenic potato plants. Plant Cell 7:1357-1368.

Wu, G., B. Shortt, E. Lawrence, J. Leon, K. Fitzsimmons, E. Levine, I. Raskin, and D. Shah. 1997. Activation of host defense mechanisms by elevated production of $\mathrm{H}_{2} \mathrm{O}_{2}$ in transgenic plants. Plant Physiol. 115:427435.

Yadav, N.R. and M.B. Sticklen. 1995. Direct and efficient plant regeneration from leaf explants of Solanum tuberosum L. cv. Bintje. Plant Cell Rpt. 14:645-647. 